\title{
Nicotinic Acetylcholine Receptor Desensitization Is Regulated by Activation-induced Extracellular Adenosine Accumulation
}

\author{
Simon Pitchford, ${ }^{1,2}$ John West Day, ${ }^{1,2}$ Adrienne Gordon, ${ }^{1,2,3}$ and Daria Mochly-Rosen ${ }^{1,2,3}$ \\ 'Ernest Gallo Clinic and Research Center and Departments of ${ }^{2}$ Neurology and ${ }^{3}$ Pharmacology, University of California, \\ San Francisco, California
}

\begin{abstract}
Adenosine modulation of nicotinic ACh receptor (nAChR) function was studied in primary cultures of rat skeletal muscle. Activation of the nAChR by carbachol increased extracellular adenosine concentration in a dose-dependent manner. Furthermore, carbachol activation of the nicotinic receptor resulted in a twofold increase in cAMP levels in the muscle cells. The carbachol-dependent increase in cAMP levels was inhibited by adenosine receptor antagonists as well as by nicotinic receptor antagonists. These results suggest that the increased CAMP levels were due to adenosine receptor activation by the extracellular adenosine accumulated on nAChR activation. Others have shown that desensitization of the nAChR by agonist is mediated, in part, by phosphorylation. Since we found that nicotinic cholinergic agonists also cause adenosine accumulation with concomitant cAMP increases, we determined whether the accumulated adenosine has a role in desensitization. We found that the adenosine receptor antagonist, BW1434U, significantly inhibited carbachol-induced nAChR desensitization, indicating that extracellular adenosine is involved in $\mathrm{nAChR}$ desensitization. Our data suggest that nAChR function is regulated via a feedback mechanism mediated by adenosine released from muscle on activation of the nAChR.
\end{abstract}

The nicotinic $\mathrm{ACh}$ receptor (nAChR) is a ligand-operated ion channel whose activation results in membrane depolarization (Stroud ct al., 1990). Similar to other ligand-gated channels, nAChRs desensitize in the continued presence of agonist (Katz and Thesleff, 1957). nAChR function can be modulated by the activation of second messenger-dependent protein kinases. cAMP-dependent protein kinase (PKA) phosphorylates the nAChR (Huganir and Greengard, 1983), resulting in an increased rate of desensitization of purified $\mathrm{nAChR}$ reconstituted into phospholipid vesicles (Huganir et al., 1986). In addition, calcium/phospholipid-dependent protein kinase C (Safran et al., 1987; Smith et al., 1989) and tyrosine-specific protein kinase (Huganir et al., 1984; Hopfield et al., 1988) phosphorylate purified nAChR. Tyrosine phosphorylation of the purified receptor also results in an increased rate of desensitization (Hopfield et al., 1988). Agents that raise intracellular cAMP and activate

\footnotetext{
Received Feb. 19, 1992; revised May 25, 1992; accepted June 22, 1992.

This work was supported by Grants K08-NS01 157 (J.W.D.) and R01-NS25537 (A.G. and D.M.R.) from NINCDS.

Correspondence should be addressed to Daria Mochly-Rosen, The Ernest Gallo Clinic and Research Center, Building 1, Room 101, San Francisco General Hospital, San Francisco, CA 94110.

Copyright (C) 1992 Society for Neuroscience $0270-6474 / 92 / 124540-05 \$ 05.00 / 0$
}

PKA have been shown to increase the rate of desensitization of the $\mathrm{nAChR}$ in intact skeletal muscle cells (Albuquerque, 1986; Middleton et al., 1986, 1988; Grassi et al., 1987). Activators of PKC also appear to increase the rate of $\mathrm{nAChR}$ desensitization (Eusebi et al., 1985, 1987; Caratsch et al., 1989). It is not clear, however, how intracellular second messenger levels required for activation of these protein kinases are increased concomitant with $\mathrm{nAChR}$ activation, since $\mathrm{nAChRs}$ are not directly coupled to second messenger generation. Two putative regulators of $\mathrm{nAChR}$ phosphorylation and function have been identified using cultured cells: (1) calcitonin genc-related peptide, which is coreleased with $\mathrm{ACh}$ at the neuromuscular junction (Fontaine et al., 1986; New and Mudge, 1986), increases nAChR phosphorylation and increases the rate of desensitization of the nAChR (Laufer and Changeaux, 1987; Mulle et al., 1988), and (2) thymopoietin also increases the rate of $\mathrm{nAChR}$ desensitization (Revah et al., 1987).

In many cell types, adenosine is an autocrine modulator of several signal transduction systems (Silinksy and Hubbard, 1973; Born et al., 1975; Wiklund et al., 1985; Gustafsson and Wiklund, 1986; Ribeiro and Sebastiao, 1987; Fowler, 1988; Fredholm and Dunwiddie, 1988; Lohse et al., 1988). Adenosine is known to be released from contracting muscle (Rubio et al., 1969; Bockman et al., 1975; Bockman and McKenzie, 1983; Thompson et al., 1986; Karim et al., 1988; Poucher et al., 1990). In addition, ATP is coreleased with ACh from motor nerve terminals into the synaptic cleft (Silinsky and Hubbard, 1973; Wagner et al., 1978; Potter and White, 1980; Keller and Zimmerman, 1983) where enzymes rapidly degrade it to adenosine (Pearson, 1985; Kreutzberg et al., 1986). It is possible, therefore, that after nerve stimulation and muscle activation, increased extracellular adenosine modulates $\mathrm{nAChR}$ activity by acting on adenosine $A_{2}$ receptors to increase cAMP. In this report, we present evidence that adenosine is released from cultured muscle cells on $\mathrm{nAChR}$ activation and regulates $\mathrm{nAChR}$ desensitization.

\section{Materials and Methods}

Materials. Adenosine, (-)- $N^{6}$-phenylisopropyladenosine (PIA), and adenosine deaminase (ADA) were purchased from Boehringer Mannheim. BW1434U was a gift from Burroughs Wellcome. 8-cyclopentyl1,3-dipropylxanthine (DPCPX) was from Research Biochemicals Inc. ZK-62711 was a gift from Berlex Laboratories (Cedar Knolls, NJ). All other chemicals, unless stated otherwise, came from Sigma Chemicals, St. Louis, MO. Some of the cell culture reagents were supplied by the Cell Culture Facility of the University of California at San Francisco.

Tissue culture. Primary cultures of neonatal rat hind limb muscle were prepared as previously described (Rubin, 1985). Briefly, 1-d-old 
A

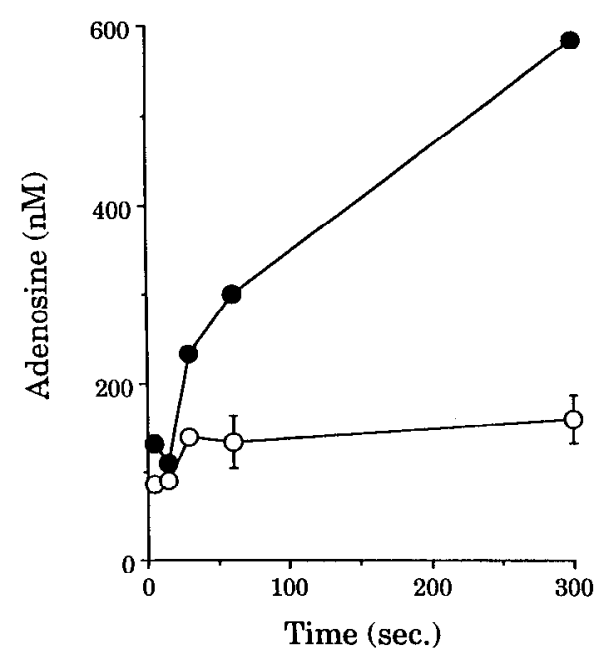

B

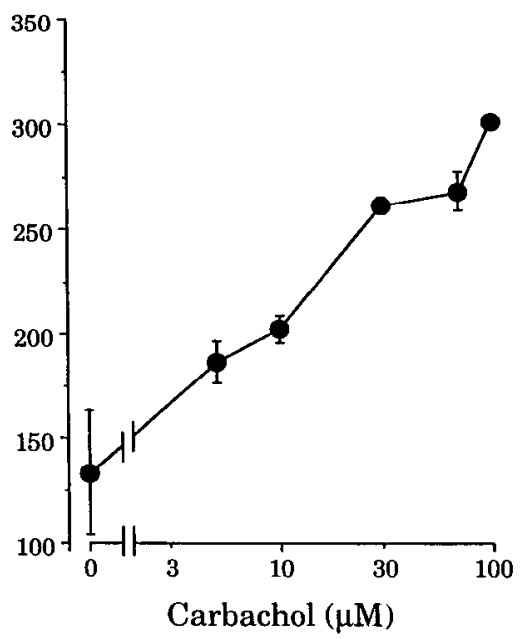

Figure 1. A, Carbachol stimulates cxtracellular adenosine accumulation in cultured muscle cells. Levels of extracellular adenosine were measured at the indicated times after incubation in the presence $(\Theta)$ or absence $(O)$ of $100 \mu \mathrm{M}$ carbachol. Results shown are representative of three experiments carried out in duplicate (mean $\pm \mathrm{SD}$ ). $B$, Extracellular adenosine accumulation is dependent on carbachol concentration. Cells were incubated with buffer containing the indicated amounts of carbachol for $1 \mathrm{~min}$. Extracellular adenosine was measured as described in Materials and Methods. A representative of four experiments is shown (mean $\pm \mathrm{SD}$ ).
Sprague-Dawley rats (Bantin and Kingman, Fremont, CA) were killed by cervical dislocation and the hind limbs removed. Following removal of the skin, the muscle was cut and subjected to $2 \times 20$ min trypsin digestions $(0.05 \%$ trypsin; Difco, Detroit, $\mathrm{MI})$ at $37^{\circ} \mathrm{C}$. Individual muscle cells were isolated by trituration. To remove the nonmuscle cells (mainly fibroblasts), cells were plated for $1 \mathrm{hr}$, after which time the less adherent muscle cells were collected and $2 \times 10^{6}$ cells were plated onto $35 \mathrm{~mm}$ collagen-coated tissue culture dishes. Cells were incubated at $37^{\circ} \mathrm{C}$ in $10 \% \mathrm{CO}_{2}$ in Dulbecco's modified Eagle's medium (DMEM; GIBCO) supplemented with $20 \%$ fetal calf serum (Hyclone), $1 \%$ glutamine, $100 \mathrm{U} / \mathrm{ml}$ penicillin, and $100 \mu \mathrm{l} / \mathrm{ml}$ streptomycin. After $48 \mathrm{hr}$, muscle cell fusion and formation of myotubes were initiated by replacing media with DMEM, $10 \%$ horse serum, $2 \%$ chick embryo extract (GIB$\mathrm{CO}), 100 \mathrm{U} / \mathrm{ml}$ penicillin, and $100 \mu \mathrm{g} / \mathrm{ml}$ streptomycin. The myotubes contracted spontaneously after $3 \mathrm{~d}$ in culture. There were $76.8 \pm 12(n$ $=13$ ) $\mathrm{nmol}$ of $\alpha$-bungarotoxin ( $\alpha$-Bgt) binding sites per $10^{6}$ cells when cells were used on day 5-6. Fibroblast cultures were obtained from the adherent cells after differential plating. They were treated in the same manner as muscle cells.

Measurement of extracellular adenosine. Myotube cultures were incubated in $2 \mathrm{ml}$ of buffer containing $130 \mathrm{~mm} \mathrm{NaCl}, 5.4 \mathrm{~mm} \mathrm{KCl}, 5 \mathrm{~mm}$ $\mathrm{CaCl}_{2}, 0.8 \mathrm{~mm} \mathrm{MgCl}_{2}, 20 \mathrm{~mm}$ HEPES, and $24 \mathrm{~mm}$ glucose, $\mathrm{pH} 7.4$, with or without carbachol. Extracellular media were collected at the indicated times and centrifuged to remove cell debris. Ammonium acetate (2.5 $\mathrm{M}, \mathrm{pH} 9.5$ ) and a fixed amount of tubericidin (as an internal standard) were added to the media. Adenosine was adsorbed on a boronate affinity column (Affigel 601, Bio-Rad), eluted, and incubated with chloracetaldehyde (Green, 1980) to form a fluorescent derivative. Samples were injected onto a reversed-phase high-pressure liquid chromatography column equilibrated with $1.2 \mathrm{mM} \mathrm{KH}_{2} \mathrm{PO}_{4}, \mathrm{pH} 5$, and the adenosine derivative eluted with a $0-60 \%$ methanol gradient. Fluorescence of the eluted sample was monitored at an excitation wavelength of $280 \mathrm{~nm}$ (Green, 1980). The adenosine peak was identified by comigration with adenosine standards and by the loss of the peak after adenosine deaminase treatment.

cAMP measurement. Myotube cultures were incubated for $60 \mathrm{~min}$ in $1 \mathrm{ml}$ of buffer (see above) containing the phosphodiesterase inhibitor $\mathrm{ZK}-62711(\mathrm{ZK} ; 10 \mu \mathrm{M})$. The cells were incubated for a further $30 \mathrm{~min}$ in the presencc and absence of appropriate drugs and the continued presence of ZK. cAMP concentrations were measured by radioimmunoassay (Koch et al., 1983; Gordon et al., 1986). In experiments with carbachol, cAMP was acetylated to increase the sensitivity of the assay.

${ }^{22}$ Sodium uptake. Myotubes were preincubated for $30 \mathrm{~min}$ at room temperature in $1 \mathrm{ml}$ of buffer in the presence or absence of adenosine receptor antagonists. Five minutes prior to the experiment, buffer was removed and replaced with $1 \mathrm{ml}$ of fresh buffer with or without $30 \mu \mathrm{M}$ carbachol. The medium was then removed and medium containing 100 $\mu \mathrm{M}$ carbachol, $1 \mu \mathrm{Ci} / \mathrm{ml}{ }^{22} \mathrm{Na}$, and $1 \mathrm{~mm}$ ouabain was added and the cells incubated for $30 \mathrm{sec}$. Cells were then washed three times at $4^{\circ} \mathrm{C}$ with buffer containing $1 \mathrm{~mm}$ ouabain and $10 \mathrm{nM} \alpha$-Bgt and incubated with $0.4 \mathrm{~N} \mathrm{NaOH}$ overnight. ${ }^{22} \mathrm{Na}$ was measured on a Beckman gamma counter.

Protein determination. Protein concentration was determined by the method of Bradford (1976).

\section{Results}

Activation of $n A C h R$ results in an increase in extracellular adenosine concentration

If adenosine modulates $\mathrm{nAChR}$ function, then receptor activation should result in extracellular adenosine accumulation in primary muscle cells. Incubation with the nicotinic cholinergic agonist carbachol resulted in a time- (Fig. $1 A$ ) and dose-dependent (Fig. $1 B$ ) increase in adenosine in the extracellular media. Increases in extracellular adenosine concentration were obtained at carbachol concentrations that produce ion channel opening, cell depolarization, and contraction (Sine and Taylor, 1979; Jackson, 1988). The nAChR antagonists Naja naja siamensis toxin (100 $\mathrm{nM}$ ) and $\alpha$-Bgt (5 $\mathrm{nM}$ ) completely inhibited the carbachol-induced adenosine accumulation $(n=3$; data not shown), indicating that $\mathrm{nAChR}$ activation is required for the increase in extracellular adenosine. Muscle cell cultures also contain nonmyocyte cells (mainly fibroblasts). However, no adenosine accumulation was observed on carbachol stimulation of nonmyocyte cultures from hind limb muscle (data not shown). These data suggest that $\mathrm{nAChR}$ activation increased the extracellular concentration of adenosine and that this adenosine originated from muscle cells.

\section{Primary muscle cells have adenosine receptors coupled to cAMP generation}

If adenosine has an autocrine effect on muscle cells, then adenosine receptors should be present on these cells. We found that PIA, an adenosine receptor agonist that acts at both $A_{1}$ and $A_{2}$ receptors (Daly, 1985), produced dose-dependent increases in cAMP in the primary muscle cells, with a half-maximal response at $5 \pm 1 \mu \mathrm{M}$ (Fig. 2). PIA-stimulated cAMP production was completely inhibited by the nonselective adenosine antagonist BW1434U (1 $\mu \mathrm{M})$ (Fig. 2). PIA did not induce cAMP production in cultures of nonmyocyte cells (data not shown). These data 


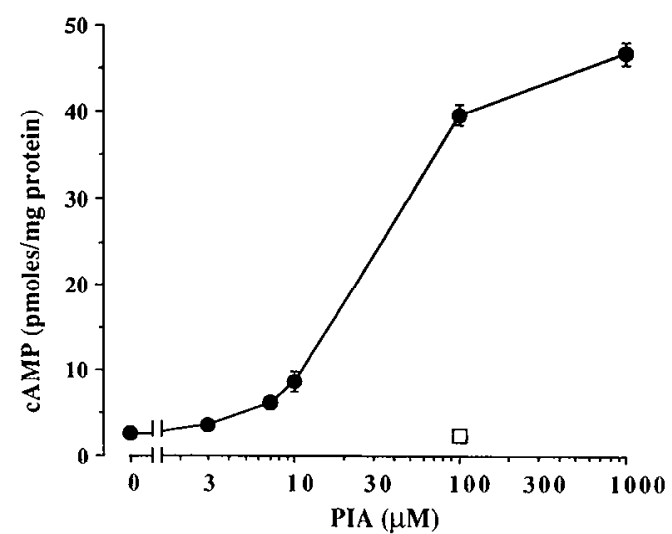

Figure 2. Adenosine $\mathrm{A}_{2}$ receptors stimulate cAMP production. Muscle cells are incubated with PIA at the indicated concentrations in the absence ( $\odot$ ) or presence $(\square)$ of $1 \mu \mathrm{M}$ BW1434U. A representative experiment of five experiments is shown (mean \pm SD).

indicate that adenosine receptors, most likely $\mathrm{A}_{2}$ receptors, couple to adenylyl cyclase to increase cAMP levels in muscle cells.

\section{Activation of $n A C h R$ increases intracellular cAMP concentration}

If the extracellular adenosine that accumulates following $\mathrm{nAChR}$ stimulation activates adenosine receptors, then cAMP levels should increase after $\mathrm{nAChR}$ activation. We found that carbachol caused a dose-dependent increase in cAMP levels (Fig. 3 , solid circles). This increase in cAMP levels is consistent with the cAMP levels reached after stimulation by adenosine at concentrations similar to those produced by carbachol (Fig. 1). For example, $100 \mu \mathrm{M}$ carbachol results in accumulation of $300 \mathrm{nM}$ adenosine (Fig. 1). At $300 \mathrm{~nm}$, adenosine causes an increase in cAMP of $86 \%$ from $3.75 \mathrm{pmol} / \mathrm{mg}$ to $7 \mathrm{pmol} / \mathrm{mg}$. A similar increase, $\sim 90 \%$, in cAMP levels over basal is obtained with $100 \mu \mathrm{M}$ carbachol (Fig. 3). Carbachol-induced cAMP generation was inhibited by incubating the muscle cell cultures with ADA (Fig. 3, open triangles), an enzyme that hydrolyzes adenosine to inosine. Inosine has a low affinity for the adenosine receptor (Daly, 1985) and therefore does not increase cAMP levels. An adenosine receptor antagonist, BW1434U, also decreased carbachol-induced cAMP levels (Fig. 3, open squares). Therefore, the increase in cAMP appears to be due to activation of adenosine receptors coupled to cAMP generation. Basal cAMP levels in muscle cells were also decreased by $\operatorname{ADA}(43 \pm 4 \%, n=11)$, or by BW1434U (Fig. 3), suggesting that even under basal conditions, adenosine is released by the muscle cells and modulates cellular cAMP levels via adenosine receptors.

Carbachol-induced increases in cAMP were due to $\mathrm{nAChR}$ activation since $5 \mathrm{nM} \alpha$-Bgt inhibited the cAMP increase by 76 $\pm 6 \%(n=6)$. Therefore, extracellular adenosine accumulation that occurs on activation of the $\mathrm{nAChR}$ by carbachol is sufficient to increase intracellular cAMP levels.

\section{Adenosine modulates $n A C h R$ desensitization}

To determine whether the extracellular adenosine that accumulates on $\mathrm{nAChR}$ activation modulates $\mathrm{nAChR}$ function, we measured desensitization of carbachol-induced ${ }^{22} \mathrm{Na}$ influx into cultured muscle cells. Incubation of cells with $100 \mu \mathrm{M}$ carbachol caused a time-dependent increase in ${ }^{22} \mathrm{Na}$ influx (data not shown). A $5 \mathrm{~min}$ preincubation with $30 \mu \mathrm{M}$ carbachol caused a reduction

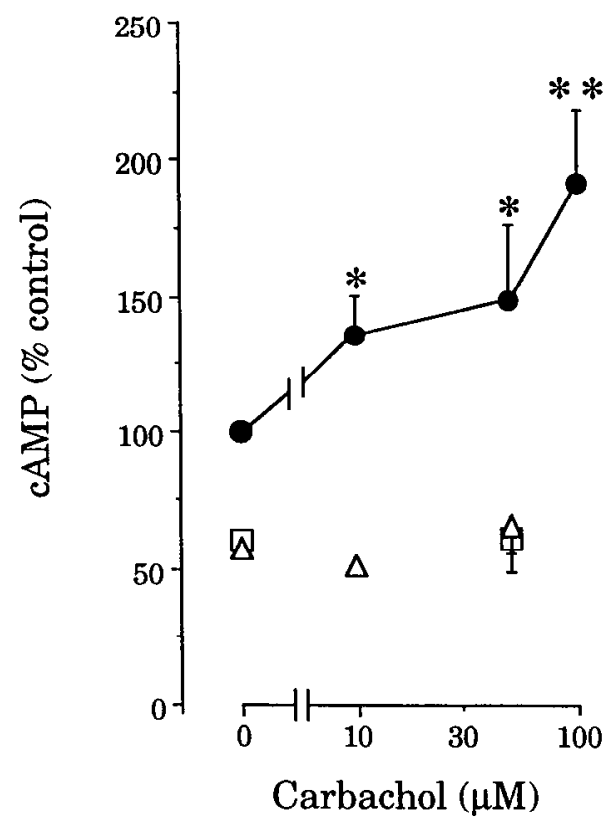

Figure 3. Carbachol increases adenosine-mediated cAMP production. Intracellular levels of cAMP were determined after incubation of cells with carbachol alone (C) or carbachol with either I $\mu \mathrm{M}$ BW1434U ( $\square$ ) or $1 \mathrm{U} / \mathrm{ml}$ ADA $(\triangle)$. Results are expressed as a percentage of cAMP produced in the absence of carbachol. cAMP levels were $7 \pm 1 \mathrm{pmol} /$ $\mathrm{mg}$ protein in the absence of carbachol and $12 \pm 2 \mathrm{pmol} / \mathrm{mg}$ protein in the presence of $100 \mu \mathrm{M}$ carbachol (mean $\pm \mathrm{SEM} ; n=5$ ). ${ }^{*}, p<0.05$; ${ }^{* *}, p<0.01$; Student's $t$ test.

in the amount of ${ }^{22} \mathrm{Na}$ influx on subsequent carbachol addition, reflecting agonist-induced desensitization of the nicotinic receptor (Catterall, 1975). Carbachol-induced desensitization averaged $72 \pm 10 \%$ (range, $43-108 \%$ ) (Fig. $4 ; p<0.0001$, twotail paired $t$ test). (Only experiments where desensitization exceeded $40 \%$ were included.) If $\mathrm{nAChR}$-mediated adenosine accumulation contributes to this desensitization, then the adenosine receptor antagonist BW1434U should inhibit desensitization (Clemo et al., 1987). In all of these experiments, a significant inhibition of nicotinic receptor desensitization by BW1434U was observed; an average of $40 \pm 10 \%$ desensitization was obtained in the presence of BW1434U (Fig. $4 ; p<$ 0.01 , two-tail paired $t$ test; $n=9$ ). Furthermore, the methylxanthine derivative isobutylmethylxanthine $(10 \mu \mathrm{M})$, another adenosine receptor antagonist (Trivedi et al., 1990), caused a similar decrease in desensitization ( $26 \pm 3 \%$ decrease; $n=2$ ). In contrast, the $A_{1}$-specific antagonist DPCPX (Bruns et al., 1987) had no effect on carbachol-induced desensitization $(0 \pm 3 \%$ decrease in desensitization; $n=2$ ). These results suggest that there is an adenosine-mediated component to the carbachol-induced desensitization. Taken together, the data presented here support the hypothesis that adenosine accumulates following $\mathrm{nAChR}$ activation and contributes to $\mathrm{nAChR}$ desensitization via activation of adenosine $A_{2}$ receptors.

\section{Discussion}

In this report, we present evidence for a novel feedback mechanism regulating $\mathrm{nACh}$ function. Activation of $\mathrm{nAChR}$ results in an increase in extracellular adenosine concentration. This increase leads to stimulation of adenylyl cyclase via $\mathrm{A}_{2}$ adenosine receptors, resulting in increased cAMP levels. We have 


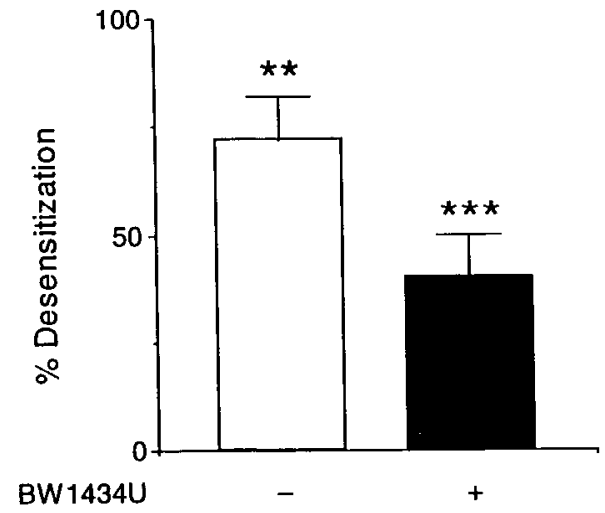

Figure 4. An adenosine receptor antagonist inhibits carbachol-induced desensitization of the AChR. Desensitization of carbachol-induced ${ }^{22} \mathrm{Na}$ influx into muscle cells in culture was produced by preexposure to 30 $\mu \mathrm{M}$ carbachol. Cells were preincubated with buffer with or without 30 $\mu \mathrm{M}$ carbachol for $5 \mathrm{~min}$ before incubation with $100 \mu \mathrm{M}$ carbachol. In experiments with antagonist, cells were incubated with $1 \mu \mathrm{M} \mathrm{BW1434U}$ for $30 \mathrm{~min}$ prior to and during the $5 \mathrm{~min}$ preincubation with $30 \mu \mathrm{M}$ carbachol. Influx obtained at $30 \mathrm{sec}$ in the presence of $100 \mu \mathrm{M}$ carbachol was defined as $0 \%$ desensitization, and nonstimulated basal influx was defined as $100 \%$ desensitization. Data are the average of nine independent experiments obtained from different cultures. ${ }^{* *}, p<0.0001$ compared to cells not preincubated with carbachol; $* * *, p<0.01$ compared to $71.7 \%$ (cells preincubated with carbachol in the absence of BW1434U); two-tail paired $t$ test.

also shown that activation-induced increases in extracellular adenosine concentration contribute to agonist-induced desensitization of the $\mathrm{nAChR}$. These results suggest that activation of the nAChR modulates its own function by an adenosinemediated mechanism.

Previous studies in other laboratories have provided evidence of a role for PKA in the modulation of $n A C h R$ activity, particularly desensitization (for reviews, see Huganir and Miles, 1989; Ochoa et al., 1989). Desensitization of the nAChR occurs in phospholipid vesicles reconstituted with purified Torpedo nAChR (Huganir et al., 1986), suggesting that desensitization can occur in the absence of other cellular components. This desensitization appears to be due to an agonist-induced conformational change in the receptor (Barrantes, 1978). Huganir et al. (1986) also demonstrated that purified nAChR, phosphorylated by PKA, desensitized at a greater rate than nonphosphorylated receptor. Therefore, it appears that there are two components to $\mathrm{nAChR}$ desensitization, both of which require the presence of agonist; one is induced directly by agonist binding and a second is mediated by $\mathrm{nAChR}$ phosphorylation (Huganir and Greengard, 1987).

Phosphorylation of the $\delta$ - and $\gamma$-subunits of $n A C h R$ by PKA has been well documented (Souroujon et al., 1986; Miles et al., 1987; Smith et al., 1987). Whether phosphorylation of the $\mathrm{nAChR}$ in intact cells results in desensitization has been the subject of some debate (Albuquerque et al., 1986; Middleton et al., 1986, 1988; Haggblad et al., 1987; Wagoner and Pallotta, 1988). However, it appears that cAMP analogs and low concentrations of forskolin enhance $n A C h R$ desensitization via cAMP (Middleton et al., 1988), presumably due to PKA-dependent phosphorylation. In our study, $\mathrm{nAChR}$ activation leads to increased extracellular adenosine accumulation with consequent increases in cAMP levels. These increases were blocked by both $\mathrm{nAChR}$ and adenosine receptor antagonists. Moreover, the adenosine receptor antagonist BW1434U partially inhibited carbachol-induced desensitization of sodium influx. These data lend support to the hypothesis that agonist-induced nAChR desensitization is, at least in part, due to increased intracellular cAMP levels and PKA-dependent phosphorylation of the nAChR.

In vivo, accumulation of extracellular adenosine due to release from muscle by cholinergic stimulation of the $\mathrm{nAChR}$ would occur in a very restricted volume at the neuromuscular junction. In addition, adenosine is produced by degradation of ATP that is coreleased with ACh on nerve stimulation (Silinsky and Hubbard, 1973). Therefore, the relative concentration of adenosine at the synapse would be expected to be higher than we observed in our cell culture system. Under these conditions, adenosine released from muscle by activation of the $\mathrm{nAChR}$ should cause even larger increases in cAMP levels and PKA activity.

In summary, our data provide evidence for a feedback mechanism in which $\mathrm{nAChR}$ desensitization is increased by extracellular adenosine produced by $\mathrm{nAChR}$ activation. The levels of extracellular adenosine increased as a function of $\mathrm{nAChR}$ stimulation. Adenosine, acting via an $\mathrm{A}_{2}$ receptor, caused increased intracellular cAMP. These increased cAMP levels appear to contribute to ACh-mediated nAChR desensitization. The function of other ligand-gated ion channels such as the GABA $_{\mathrm{A}}$ (Porter et al., 1990) and glutamate receptors (Greengard et al., 1991; Wang et al., 1991) is also modulated by PKA phosphorylation. Since adenosine is secreted by most cells and adenosine is produced from ATP released in synaptic vesicles, the function of other ligand-gated ion channels in addition to the $\mathrm{nAChR}$ may be modulated by adenosine.

\section{References}

Albuquerque EX, Deshpande SS, Aracava Y, Alkondon M, Daly JW (1986) A possible involvement of cyclic AMP in the expression of desensitization of the nicotinic acetylcholine receptor. FEBS Lett 199: 113-120.

Barrantes FJ (1978) Agonist-mediated changes of the acetylcholine receptor in its membrane environment. J Mol Biol 124:1-26.

Bockman EL, McKenzie JE (1983) Tissue adenosine content in active soleus and gracilis muscles of cats. Am J Physiol 244:H552-H559.

Bockman EL, Berne RM, Rubio R (1975) Release of adenosine and lack of release of ATP from contracting skeletal muscle. Pfluegers Arch 355:229-241.

Born GVR, Haslam RJ, Gelman M, Lowe RD (1975) Comparative effectiveness of adenosine analogues as inhibitors of blood-platelet aggregation and as vasodilators in man. Nature 205:678-680.

Bradford $M$ (1976) A rapid and sensitive method for the quantitation of microgram quantities of protein utilizing the principle of proteindye binding. Anal Biochem 72:248-254

Bruns RF, Fergus JH, Badger EW, Bristol JA, Santay LA, Hartman JD, Hays SJ, Huang CC (1987) Binding of the $A_{1}$-selective adenosine agonist 8-cyclopentyl-1,3-dipropylxanthine to rat brain membranes. Naunyn- Schmiedebergs Arch Pharmacol 335:59-63.

Caratsch CG, Knoflach F, Grassi F, Eusebi F (1989) Regulation of acetylcholine receptor function by the phorbol ester TPA in rat skeletal muscle. Naunyn Schmiedebergs Arch Pharmacol 340:82-86.

Catterall WA (1975) Sodium transport by the acetylcholine receptor in cultured muscle cells. J Biol Chem 250:1776-1781.

Clemo HF, Bourassa A, Linden J, Belardinelli L (1987) Antagonism of the effects of adenosine and hypoxia on atrioventricular conduction time by two novel alkylxanthines: correlation with binding to adenosine Al receptors. J Pharmacol Exp Ther 242:478-484.

Daly JW (1985) Adenosine receptors. Adv Cyclic Nucleotide Protein Phosphorylation Res 19:29-46.

Eusebi F, Molinaro M, Zani BM (1985) Agents that activate protein kinase $\mathrm{C}$ reduce acetylcholine sensitivity in cultured myotubes. J Cell Biol 100:1339-1342.

Eusebi F, Grassi F, Nervi C, Caparale C, Adamo S, Zani BM, Molinaro 
M (1987) Acetylcholine may regulate its own nicotinic channel through the C-kinase system. Proc R Soc Lond [Biol] 230:355-365.

Fontaine B, Klasfeld A, Hokfelt T, Changeux JP (1986) Calcitonin gene-related peptide, a peptide present in spinal cord motorneurons, increases the number of acetylcholine receptors in primary cultures of chick embryo myotubes. Neurosci Lett 71:59-65.

Fowler JC (1988) Modulation of neuronal excitability by endogenous adenosine in the absence of synaptic transmission. Brain Res 463: 368-373.

Fredholm BB, Dunwiddie TV (1988) How does adenosine inhibit transmitter release. Trends Pharmacol Sci 9:130-134.

Gordon AS, Collier K, Diamond I (1986) Adenosine is required for ethanol-induced heterologous desensitization. Proc Natl Acad Sci USA 83:2105-2108.

Grassi F, Monaco L, Eusebi $\Gamma$ (1987) Acetylcholine receptor channel properties in rat myotubes exposed to forskolin. Biochem Biophys Res Commun 147:1000-1007.

Green RD (1980) Release of adenosine by C1 300 neuroblastoma cells in tissue culture. J Supramol Struct 13:175-182.

Greengard P, Jen J, Nairn AC, Stevens CF (1991) Enhancement of the glutamate response by cAMP-dependent protein kinase in hippocampal neurons. Science 253:1135-1138.

Gustafsson LE, Wiklund NP (1986) Adenosine-modulation of cholinergic and non-adrenergic non-cholinergic neurotransmission in the rabbit iris sphincter. Br J Pharmacol 88:197-204.

Haggblad J, Eriksson H, Hedlund B, Heilbronn E (1987) Forskolin blocks carbachol-mediated ion-permeability of chick myotube nicotinic receptors and inhibits binding of ${ }^{3} \mathrm{H}$-phencyclidine to Torpedo microsac nicotinic receptors. Naunyn Schmiedebergs Arch Pharmacol 336:381-386

Hopfield JF, Tank DW, Greengard P, Huganir RL (1988) Functional modulation of the nicotinic acetylcholine receptor by tyrosine phosphorylation. Nature 336:677-680.

Huganir RL, Greengard P (1983) cAMP-dependent protein kinase phosphorylates the nicotinic acetylcholine receptor. Proc Natl Acad Sci USA 80:1130-1134.

Huganir RI, Greengard P (1987) Regulation of receptor function by protein phosphorylation. Trends Pharmacol Sci 8:472-477.

Huganir RL, Miles K (1989) Protein phosphorylation of nicotinic acetylcholine receptors. Crit Rev Biochem Mol Biol 24:183-215.

Huganir RL, Miles K, Greengard P (1984) Phosphorylation of the nicotinic acetylcholine receptor by an endogenous tyrosine-specific protein kinase. Proc Natl Acad Sci USA 81:6968-6972.

Huganir RL, Delcour AH, Greengard P, Hess GP (1986) Phosphorylation of the nicotinic acetylcholine receptor regulates its rate of desensitization. Nature 321:774-776.

Jackson MB (1988) Dependence of acetylcholine receptor channel kinetics on agonist concentration in cultured mouse muscle fibers. $J$ Physiol (Lond) 397:555-583.

Karim F, Ballard HJ, Cotterrel D (1988) Changes in adenosine release and blood flow in the contracting dog gracilis muscle. Pfluegers Arch 412:106-112.

Katz B, Thesleff S (1957) A study of the "desensitization" produced by acetylcholine at the motor end-plate. J Physiol (Lond) 138:63-80.

Keller F, Zimmermann H (1983) Ecto-adenosine triphosphatase activity at the cholinergic nerve endings of the Torpedo electric organ. Life Sci 33:2635-2641.

Koch TK, Gordon AG, Diamond I (1983) Phospholipid methylation in myogenic cells. Biochem Biophys Res Commun 114:339-347.

Kreutzberg GW, Heymann D, Reddington M (1986) 5'-Nucleotidase in the nervous system. In: Cellular biology of ectoenzymes (Kreutzberg GW, Reddington M, Zimmerman H, eds), pp 147-164. Berlin: Springer.

Laufer R, Changeux JP (1987) Calcitonin gene-related peptide elevates cyclic AMP levels in chick skeletal muscle: possible neurotrophic role for a coexisting neuronal messenger. EMBO J 6:901-906.

Lohse MJ, Klotz KN, Salzer MJ, Schwabe U (1988) Adenosine regulates the $\mathrm{Ca}^{2+}$ sensitivity of mast cell mediator release. Proc Natl Acad Sci USA 85:8875-8879.

Middleton P, Jaramillo F, Schuetze SM (1986) Forskolin increases the rate of acetylcholine receptor desensitization at rat soleus endplates. Proc Natl Acad Sci USA 83:4967-4971.

Middleton P, Rubin LL, Schuetze SM (1988) Desensitization of acetylcholine receptors in rat myotubes is enhanced by agents that elevate intracellular cAMP. J Neurosci 8:3405-3412.
Miles K, Anthony DT, Rubin LL, Grcengard P, Huganir RL (1987) Regulation of nicotinic acetylcholine receptor phosphorylation in rat myotubes by forskolin and cAMP. Proc Natl Acad Sci USA 84:65916595.

Mulle C, Benoit P, Pinset C, Roa M, Changeux J (1988) Calcitonin gene-related peptide enhances the rate of desensitization of the nicotinic acetylcholine receptor in cultured mouse muscle cells. Proc Natl Acad Sci USA 85:5728-5732.

New HV, Mudge AW (1986) Calcitonin gene-related peptide regulates muscle acetylcholine receptor synthesis. Nature 323:809-811.

Ochoa ELM, Chattopadhyay A, NcNamee MG (1989) Desensitization of the nicotinic acetylcholine receptor: molecular mechanisms and effect of modulators. Cell Mol Neurobiol 9:141-178.

Pearson JD (1985) Ectonucleotidases. Methods Pharmacol 6:83-107.

Porter NM, Twyman RE, Uhler MD, MacDonald RL (1990) Cyclic AMP-dependent protein kinase decreases $\mathrm{GABA}_{\mathrm{A}}$ receptor current in mouse spinal neurons. Neuron 5:789-796.

Potter P, White TD (1980) Release of adenosine 5 -triphosphate from synaptosomes from different regions of the brain. Neuroscience 5: 1351-1356.

Poucher SM, Nowell CG, Collis MG (1990) The role of adenosine in exercise hyperaemia of the gracilis muscle in anaesthetized cats. $J$ Physiol (Lond) 427:19-29.

Revah F, Mulle C, Pinset C, Audhya T, Goldstein G, Changeux J-P (1987) Calcium-dependent effect of the thymic polypeptide thymopoietin on the desensitization of the nicotinic acetylcholine receptor. Proc Natl Acad Sci USA 84:3477-3481.

Ribeiro JA, Sebastiao AM (1987) On the role, inactivation and origin of endogenous adenosine at the frog neuromuscular junction. J Physiol (Lond) 384:571-585.

Rubin LL (1985) Increases in $\mathrm{Ca}^{2+}$ mediate changes in acetylcholinesterase and acetylcholine receptors caused by muscle contraction. Proc Natl Acad Sci USA 82:7121-7125.

Rubio R, Berne RM, Katori M (1969) Release of adenosine in reactive hyperemia of the dog heart. Am J Physiol 216:56-62.

Safran A, Sagi-Eisenbeg R, Neumann D, Fuchs S (1987) Phosphorylation of the acetylcholine receptor by protein kinase $C$ and identification of the phosphorylation site within the receptor $\delta$ subunit. $J$ Biol Chem 262:10506-10510.

Silinsky EM, Hubbard JI (1973) Release of ATP from rat motor nerve terminals. Nature 243:404-405.

Sine S, Taylor $P$ (1979) Functional consequences of agonist-mediated state transitions in the cholinergic receptor. J Biol Chem 254:33153325.

Smith MM, Merlie JP, Lawrence JC Jr (1987) Regulation of phosphorylation of nicotinic acetylcholine receptors in mouse $\mathrm{BC} 3 \mathrm{HI}$ myocytes. Proc Natl Acad Sci USA 84:6601-6605.

Smith MM, Merlie JP, Lawrence JC Jr (1989) $\mathrm{Ca}^{2+}$-dependent and cAMP-dependent control of nicotinic acetylcholine receptor phosphorylation in muscle cells. J Biol Chem 264:12813-12819.

Souroujon MC, Neumann D, Pizzighella D, Fridkin M, Fuchs S (1986) Mapping of the cAMP-dependent phosphorylation sites in the acetylcholine receptor. EMBO J 5:543-546.

Stroud RM, McCarthy MP, Shuster M (1990) Nicotinic superfamily of ligand-gated ion channels. Biochemistry 29:11009-11023.

Thompson LP, Gorman MW, Sparks HV (1986) Aminophylline and interstitial adenosine during sustained exercise hyperemia. Am $J$ Physiol 251:H1232-H1243.

Trivedi BK, Bridges AJ, Bruns RF (1990) Structure-activity relationships of adenosine $A 1$ and $A 2$ receptors. In: Adenosine and adenosine receptors (Williams M, ed), pp 57-103. Clifton, NJ: Humana.

Wagner JA, Carlson SS, Kelly RB (1978) Chemical and physical characterization of cholinergic synaptic vesicles. Biochemistry 17:11991206.

Wagoner PK, Pallotta BS (1988) Modulation of acetylcholine receptor desensitization by forskolin is independent of cAMP. Science 240: 1655-1657.

Wang L-Y, Salter MW, MacDonald JF (1991) Regulation of kainatc receptors by cAMP-dependent protein kinase and phosphatases. Science 253:1132-1135.

Wiklund P, Gustafsson LE, Lundin J (1985) Pre- and postjunctional modulation of cholinergic neuroeffector transmission by adenine nucleotides. Experiments with agonist and antagonist. Acta Physiol Scand 125:681-691. 